\title{
Análise da pedometria no diagnóstico de enfermidades podais em vacas leiteiras
}

Mirian Rodrigues, Fábio Henrique Bezerra Ximenes, José Ricardo Barbosa Silva, Celso Antonio Rodrigues

Departamento de Cirurgia e Anestesiologia Veterinária, Faculdade de Medicina Veterinária e Zootecnia, Universidade Estadual Paulista (UNESP), Botucatu, SP, Brasil

*Autor correspondente

e-mail: mrodrigues@fmvz.unesp.br

\section{Resumo}

$\mathrm{Na}$ bovinocultura de leite, as afecções podais acarretam na redução da vida útil produtiva, pois além de prejudicar o bem estar animal, também diminui principalmente a produção leiteira. Avaliar a prevalência das lesões podais dentro do rebanho leiteiro é importante para uma boa gestão. Contudo, a detecção automatizada de vacas claudicantes é útil em grandes rebanhos, pois reduz o tempo de avaliação e apresenta maior sensibilidade do que o método tradicional de observação. 0 presente trabalho objetivou a identificação precoce de lesões podais oriundas da laminite e infecciosas, em vacas da raça Holandesa Preta e Branca (HPB) de alta produção, a partir de alterações na pedometria. Foram selecionadas 245 de um universo de 1.600 vacas, em regime de criação intensivo (Free-Stall), que em 44 semanas de lactação não apresentaram as seguintes enfermidades: mastite clínica, deslocamento de abomaso, pneumonia, hipocalcemia, retenção de placenta, metrite, diarreia e cetose. Os dados pedométricos foram obtidos por meio de leitor automático contabilizados pelo pedômetro, posicionado no terço distal do metatarso dos animais, e compreenderam o número de passos por dia, calculando média semanal (44 médias/animal). 0 exame dos dígitos foi realizado de forma aleatória, durante a rotina, sendo coletados dados referentes à primeira ocorrência de lesão podal relativa ao período de lactação de cada animal. A avaliação das 245 vacas revelou que $75,91 \%$ não apresentaram nenhum tipo de lesão podal ao longo da lactação (G1), outras 5,71\% apresentaram lesões associadas à laminite (G2), 12,24\% foram acometidas por lesões infecciosas (G3) e $6,12 \%$ foram acometidas pelas sequelas de laminite e enfermidades infecciosas conjuntamente (G4). Na análise descritiva dos grupos, o G1 apresentou o maior número de passos, enquanto que o G4 apresentou o menor número de passos, provavelmente devido ao mecanismo de dor causado pelas lesões que levam a alterações de comportamento como a diminuição na frequência de locomoção. Na análise caso/controle, 
foram formados três grupos: animais sem lesão (SL), animais com lesão de laminite (LL), animais com lesão infecciosa (LI). Tanto os animais LL quanto LI tiveram menor número de passos quando comparados com animais SL. Assim ocorreu também durante as cinco semanas que antecederam as lesões, ou seja, os animais com lesões podais apresentaram menor número de passos nas cinco semanas antecedentes à lesão quando comparados com animais sadios. Estes resultados evidenciaram novamente que animais com lesão podal diminuem sua atividade pedométrica devido à dor que estas afecções causam no aparelho locomotor. 